\title{
RENOVATION OF MATURE DESTINATIONS: THE CASE OF THE PLAYA DE SAN JUAN
}

\author{
I. RUIZ ${ }^{1}$, B. SERRANO ${ }^{2} \&$ R. TEMES ${ }^{1}$ \\ ${ }^{1}$ Universitat Politècnica de València, Spain \\ ${ }^{2}$ Instituto Valneciano de la Edificación, Universitat Politècnica de València, Spain
}

\begin{abstract}
This paper is a partial result of the Research Project 'Strategies for sustainable regeneration in tourism settlements on the Mediterranean Coast, ERAM' (ref. BIA2011-28297-C02-01) Spain National Plan of Research, 2011. In this project, the authors are studying the problem of the obsolete tourist destinations. Tourist cities emerged in Spain as a result of the tourist boom of the 60s, the phenomenon was called mass tourism. This means that our tourist spaces have a seniority of 50 years and hardly count with the functionality and services required in this time. In this study, we are working on the renovation of mature destinations. It is based on the analysis of the urban planning of one of the municipal districts in Costa Blanca, Playa de San Juan in Alicante, and the capacity of this localization as a tourist destination nowadays. To develop this task, we are studying the building typologies, the tourist facilities and the urban planning conditions. Then, we put all the information in a geographic information system (GIS), and we make thematic maps to analyse the information. Given the implication that the tourism industry has in the Spanish economy and assuming the antiquity of our tourist destinations, it is necessary to make a reflection on the future of tourist cities. It is time to approach the sustainable urban regeneration of our tourist destinations, assuming the nature of its origin and recognizing its built heritage as a differentiator. This study takes as a work element the Playa de San Juan de Alicante, taking as a base on the analysis of the urban area, the authors propose strategies for sustainable urban regeneration of obsolete tourist destinations.

Keywords: Architecture and tourism, Coastal zones, Heritage Management, sea and sand destination, Tourist renewal strategies, urban regeneration, urban renewal.
\end{abstract}

\section{INTRODUCTION AND OBJECTIVES}

This article presents part of the results of a research project carried out from the Polytechnic University of Valencia, referred to as the ERAM Project [1], the purpose of which is to address the study of the sustainable regeneration of tourist settlements in the Spanish Mediterranean basin. In order to examine the issue of the obsolescence of tourist destinations, the document before us uses the San Juan Beach in Alicante as a case study.

Spain has traditionally been a sun, sea and sand destination ever since its development in the wake of the tourism boom of the 1960s, a phenomenon that Pie, Volanova \& Diaz referred to as 'mass tourism' [2]. The evolution of tourism in Spain brought with it a move from national holiday taking, in vogue since the beginning of the 20th century and which entailed taking up residence in a second summer home or renting lodgings for a lengthy summer holiday with all the family, to the tourism boom of the 1950s which, promoted by central government, reached its peak in the 1960s and 1970s, according to Pie and Rosa [3]. This implies that our tourist towns, built in response to the mass tourism of the 1960s, are now about 50 years old, and they are unlikely to possess the functionality and features that such 
spaces require in today's world. The Spanish tourism industry has a strong impact on the Spanish economy, and it has established itself, as can be seen in the 2013 Exceltur Report [4], as the main driving force behind the country's economic recovery, with a 0.6 increase in the GDP with respect to the previous year. However, one must assume the age of our tourist destinations and reflect on the future of the tourist cities in Spain.

The objective of this work has been to examine the concept of obsolescence and aging of tourism spaces, taking the San Juan Beach as a case study. To do so, a diagnosis was carried out of that space as a tourist area, identifying the key factors behind its degradation. On the basis of this diagnosis, sustainable urban regeneration proposals will be put forward aimed at improving the area's economic competitiveness.

This case study was chosen in the first instance, because it is a mature tourist destination showing signs of economic stagnation, as per the Caixa Index, a synthetic index of tourism evolution, which compares the tourist importance of a municipality over an interval of time, according to Temes [5]. Secondly, San Juan Beach was chosen because it is a tourist area that came into existence as the result of an ex professo 1960s' urban planning development in response to the urgent needs of the so-called tourism boom. The origin of the urban planning development gives us the opportunity to identify and gives value to its twentieth century heritage and to offer new tourist attractions.

As Agarwal suggests [6] in his review of Butler's tourist destination life cycle model [7], when a tourist destination reaches the stagnation stage, it is possible to reposition the tourism destination by realigning or supplementing its attractions. However, according to Butler's model, if a declining tourism destination is to maintain its stability or stimulate its rejuvenation, the options available to that destination necessarily imply the transformation of the existing tourism model.

In our case study to transform the existing tourism model, three strategies are proposed. The first consists of maximising the area's identifiable 20th century architectural assets, beginning with the very urban planning development that gave rise to the tourist area that we know today, namely the 'Urban Planning Development of San Juan Beach, Polygon 1' by Guardiola Gaya, 1959 (Fig. 1). In this urban planning development, the architect proposes a volumetric configuration of the buildings with each block comprising different types of con-

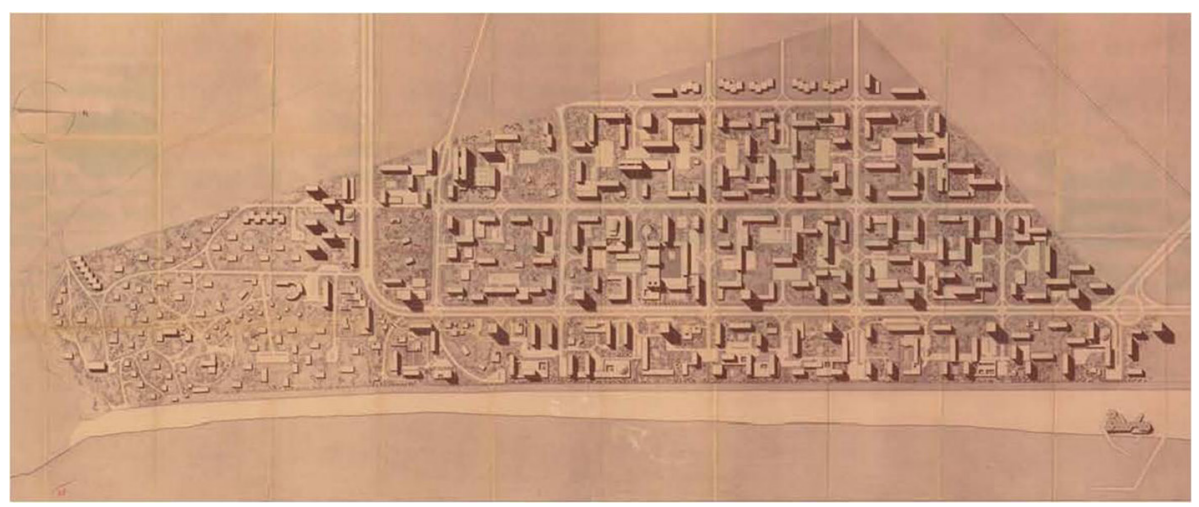

Figure 1: Urban Planning Development of San Juan Beach, Polygon 1, by Guardiola Gaya, 1959. Source: The municipal archive of Alicante. Dossier-8888-901/0 (Alicante). 
structions. As part of elements of distinction, the architect proposes constructing several towers at points set out along the development of principal avenue, which he moved back from the seafront so that it might cope with the traffic. With that in mind, the second strategy that is proposed involves the 'Milestone-Towers' that Guardiola Gaya introduced in his urban development plan, as configurative elements of the image of the proposal.

The final strategy that is proposed to transform the existing tourism model at San Juan Beach, is the implementation of a programme of sensitisation and dissemination to make local inhabitants and tourists aware of the heritage value of the urban space that is theirs to enjoy.

\section{METHODOLOGY}

These are the stages of the work. The method used may best be understood as a hypotheticaldeductive method. In this case, it is being proposed as a hypothesis, fruit of the previously know data set. Based on data gathered and on the collection of existing information on the topic, analysis takes place, during which phase four key strategies will be proposed.

The first strategy will analyse San Juan Beach as a present-day tourist area. In order to determine the quality of San Juan Beach as a tourist city, it will be compared against certain tourism benchmarks. The work method used will begin by evaluating the established analysis parameters. The linear summation of all the parameters will give us a value for each building and its urban environment. We will analyse this data with the help of multicriteria analysis tables, in which, based on different parameter weights, different analysis scenarios will be defined. All data obtained will be deployed in a Geographical Information System that will allow us to interpret the data (Figs. 2 and 3).

The organisation of the information that is to be analysed is based on the elaboration of tabs for each of the blocks of the area under study, which is based on their cadastral data, will include the assessment of the parameters defined for the analysis of the public space. Within each block, other tabs will be created to analyse each of the buildings found in the block being studied to collect cadastral data, and to evaluate in this case, the parameters that have been defined analyse the building and to what extent it adapts to the existing planning. This urban analysis will allow us to identify the worst and the best blocks both from the point of view of the value of the public spaces and of their edification; based on this analysis, we will determine the optimal location to undertake an urban regeneration strategy for San Juan Beach.

The second strategy posed in this analysis phase assesses and compares the regulatory frameworks of other Autonomous Communities that lead the way in passing laws aimed at renewing and defining quality standards for their tourist infrastructure, such as the Canary Islands and the Balearic Community. The legislative foresight of these two communities has brought positive results, according to the Summer 2013 Exceltur Report [4], which identifies both communities as the most favoured destinations by demand determinants. In this regard, State Law 8/2013, concerning rehabilitation, regeneration and urban renewal [8], places emphasis on the need to modernize the tourism sector and implies a commitment to policies for action on existing urban fabrics, actions that contemplate entire neighbourhoods.

With regard to the third strategy, we have considered applying the Guide of Strategies for Urban Regeneration [9] as a case study. Based on this document (which was designed for residential urban spaces), we checked the basic principles of integrated urban regeneration applied to our tourism space. These principles are summarised in seven defined strategies; Strategy 1: Urban land as the physical basis of the transformation, Strategy 2: Urban mor- 


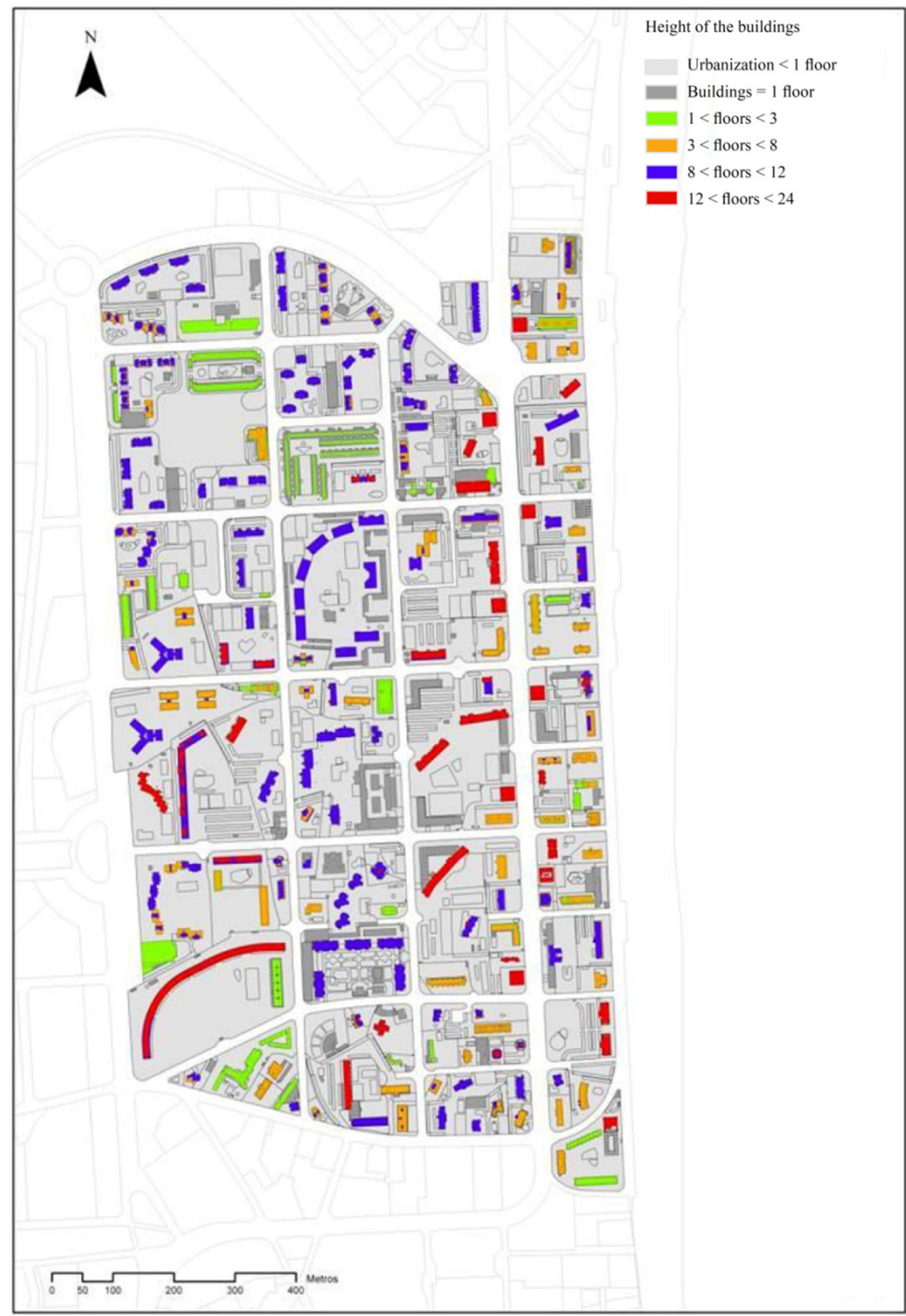

Figure 2: Analysis plan of the height of the buildings within the San Juan Beach study field (Alicante). Source: Prepared by the authors. 


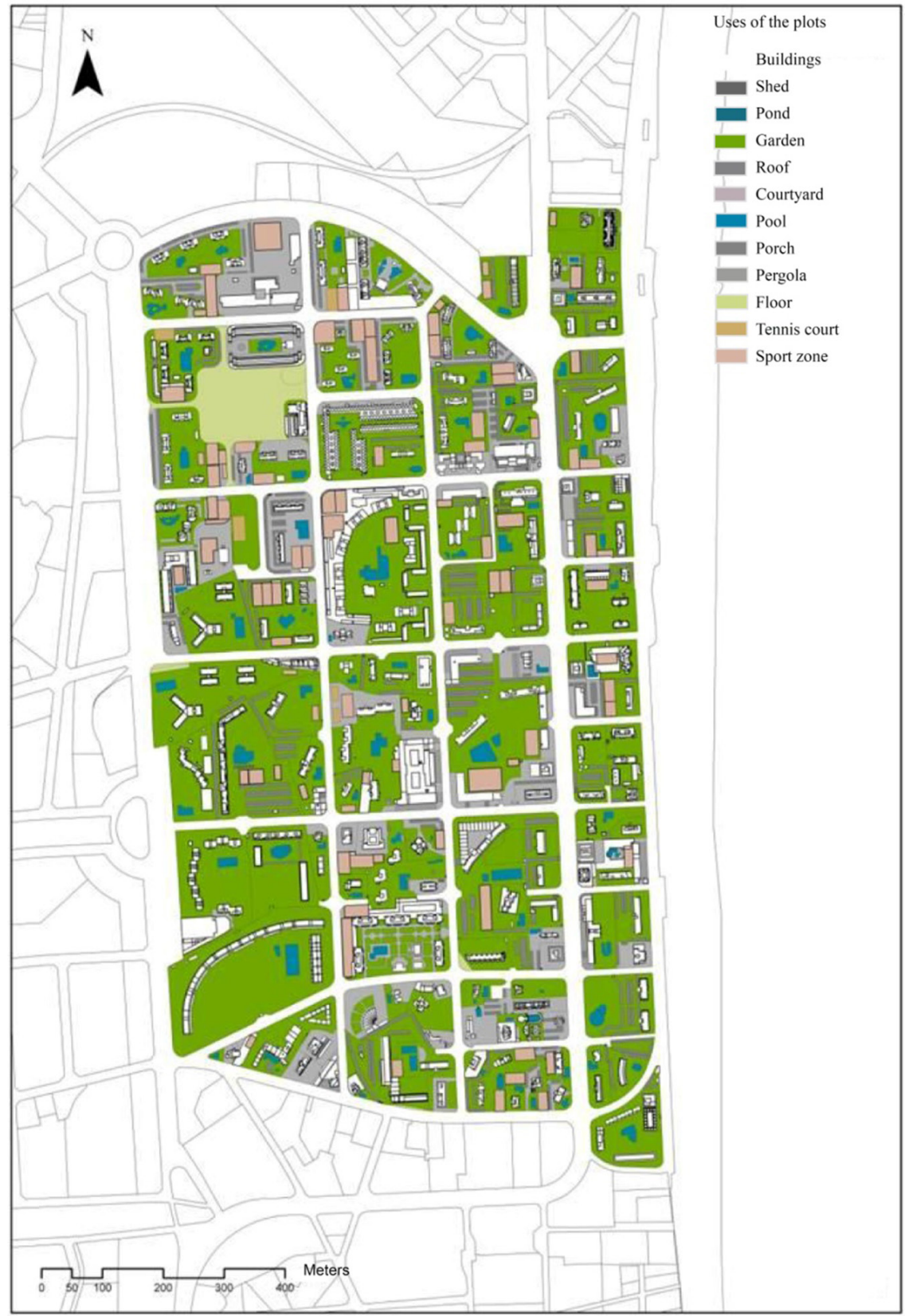

Figure 3: Analysis plan of the uses of the plots within the field of study of San Juan Beach (Alicante). Source: Prepared by the authors. 


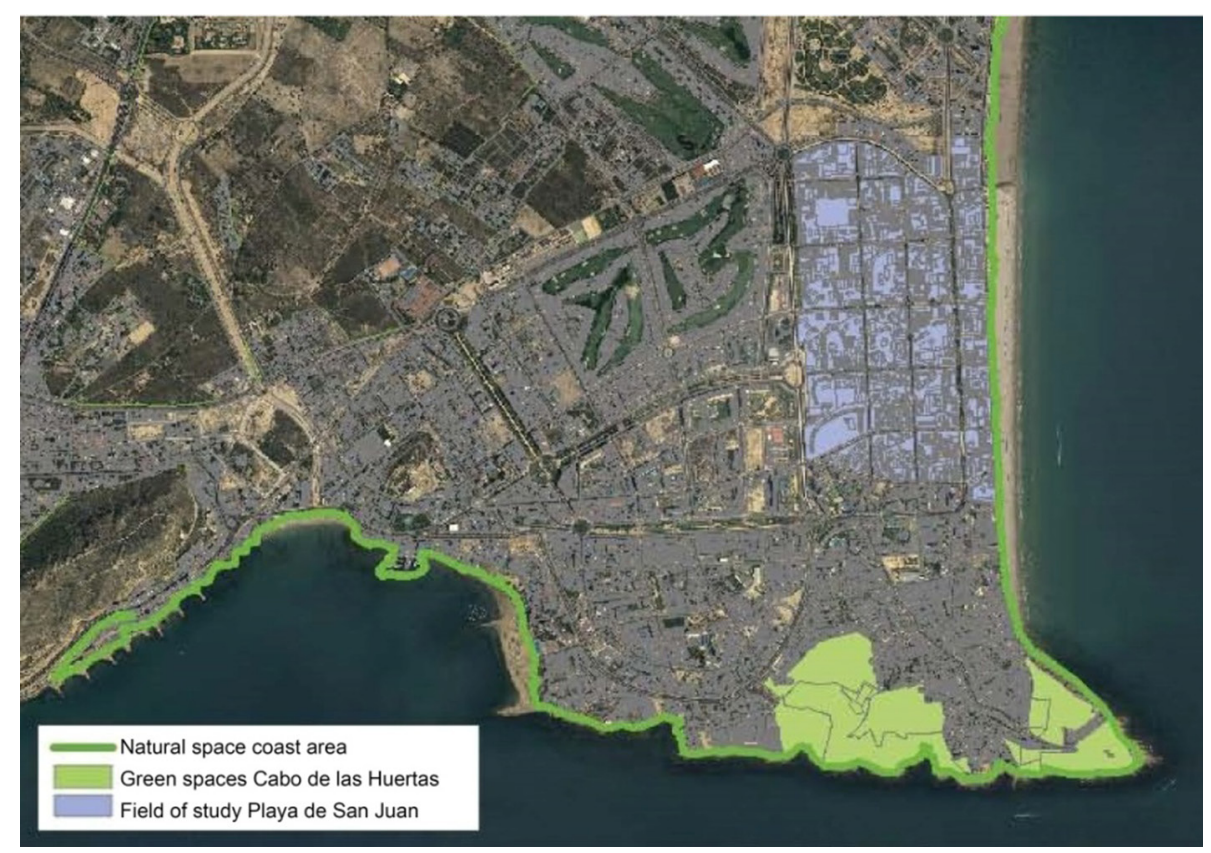

Figure 4: Strategy 1 analysis plan. High-impact green spaces in the area, related to our field of study, San Juan Beach (Alicante). Marked in blue. Source: Prepared by the authors.

phology as a working tool, Strategy 3: Urban mobility as an inherited right, Strategy 4: Natural resources as food bank in crisis, Strategy 5: Social structure as a guarantee for urban management, Strategy 6: The economic model as a driving force for change, Strategy 7: Governance as a re-balancing tool. The following illustration provides an example of the analysis of strategy 1, Urban land as the physical basis of the transformation, within our field of study (Fig. 4).

With regard to the last of the strategies broached during the analysis phase of San Juan Beach, we propose identifying as tourist resources the architectural assets from the 20th century that are to be found in the study area. Once we reach the diagnostic phase, strategies for the sustainable urban regeneration of San Juan Beach in Alicante will be put forward, aimed at improving the competitiveness of the tourism industry and at placing value on its 20th century architecture, bringing this research to an end by drawing up the conclusions of the work.

\section{RESULTS AND DISCUSSION}

The urban analysis of San Juan Beach has made it possible to determine to what extent it is valid as a tourism space, based on the study of parameters of functionality and to what extent it adapts to current and envisaged planning for the area and to tourism benchmarks. This analysis has also allowed us to establish an evaluation ranking of the blocks according to the analysis parameters that were established, making it possible for us to select one of them to carry out an operation of sustainable urban regeneration, that is, the structural, energy and functional rehabilitation of the Aisa Tower. 
The aim of this proposal is to convert the Aisa Tower, a 1960s apartment block, into a highperformance building in line with today's tourism requirements. Once the Aisa Tower has been rehabilitated, a tourism management system will be introduced that will allow proprietors to use it as a second home during the season, and to make it available as a tourism product throughout the rest of the year.

However, the key to the defined model for the rehabilitation and the tourist management of the Aisa Tower so that it may have an impact on the tourism product offered at San Juan Beach, is that should be an action model that can be extrapolated to the other 'Milestonetowers' that Guardiola Gaya proposed in his urban development plan, not only in this initial polygon but also throughout the entire beach area, given that they all have identical characteristics. Thereby becoming a seed that spreads throughout the tourism field, diversifying and qualifying the existing tourist offer.

\section{CONCLUDING REMARKS}

This study has raised the issue of the heritage value of the urban proposal that gave rise to this tourist area, the Urban Planning Development of San Juan Beach, Polygon 1, work of architect Juan Guardiola Gaya in 1959, which, in line with the canons of the modernist movement, put forward solutions that were innovative at that time and proposed quality management for the area, both in the planning of the volumes of its buildings and of the layout of the blocks. This project is considered, according to certain authors such as Fernando Terán, to be a clear example of the survival of the urban planning of the Modernist Movement, and to have undeniable quality within its systematization and its formal clarity [10].

Today, San Juan Beach preserves the principal traces of the Urban Planning Development of San Juan Beach, Polygon 1, the concept of open building and eight of the ten 'Milestonetowers' that the architect proposed to give shape to the proposal's main avenue. With this work, we seek to protect and restore this example of 20th century urban planning, preserving in this way both the historical memory and the raison d'être of Alicante's San Juan Beach tourist area.

Taking into account that the PGOMU of Alicante envisages for the future of the area a maximum height of 10 floors and $0.70 \mathrm{~m}^{2}$ roof $/ \mathrm{m}^{2}$ floor as a maximum buildable value, and that currently barely 15 percent of the buildings meet these parameters, the future urban space of San Juan Beach will be an environment with a lower density and lower building heights. Therefore, promoting the protection of the 'Milestone-towers' as part of the Urban Planning Development of Polygon 1 would serve to safeguard the memory of the origin of San Juan Beach and to allow it to recover its leading role in the planning of the area.

By placing value on the Patrimonial Assets of 20th century Architecture, we would manage to realign the area's tourist attractions, and we would ensure that the society would be more aware of its value and would appreciate the architectural heritage of the environment, increasing the awareness of local residents and visitors to the area. Meanwhile, our proposal to renovate the Aisa Tower would increase and diversify the tourist accommodation that is available, alleviate the seasonality by managing the occupancy of the apartments throughout the year and improve the business prospects of the area's tourism industry, collaborating in this way in the economic stimulation of San Juan Beach.

\section{REFERENCES}

[1] ERAM. Strategies for sustainable regeneration in tourism settlements on the Mediterranean Coast. Spain National Plan of Research, ref. BIA2011-28297-C02-01, 2011. 
[2] Pié, R., Volanova, J.M. \& Díaz, P., Del Grand Tour al turismo de masas. Cuadernos del territorio, La Coruña núm, 2, pp. 57-67, 2010.

[3] Pié, R. \& Rosa, C., Turismo Líquido. Malaga: Autores, Universidad de Málaga y ETSA Málaga, 2010

[4] Exceltur, CEO Barómetro de la Rentabilidad y Empleo de los Destinos Turísticos Españoles. Verano de 2013, Exceltur: Madrid, 2014.

[5] Temes, R., A system of synthetic indicators for the diagnosis of regulated tourist areas of the valencian coast. WIT Transactions on Ecology and the Environment, 191, pp. 259-270, 2014. ISSN 1743-3541. http://dx.doi.org/10.2495/SC140221

[6] Agarwal, S., Restructuring seaside tourism the resort lifecyle. Annals of Tourism Research, 29(1), pp. 25-55, 2002.

http://dx.doi.org/10.1016/S0160-7383(01)00002-0

[7] De España, J.C.I.R., Ley 8/2013, de 26 de junio, de rehabilitación, regeneración y renovación urbanas. Boletín Oficial del Estado, 27, 2013.

[8] Butler, R.W., The concept of a tourist area cycle of evolution: implications for management of resources. Canadian Geographer, 24(1), pp. 5-12, 1980. http://dx.doi.org/10.1111/j.1541-0064.1980.tb00970.x

[9] Gasco, C., Mateo, F., Sauer, B., Ballester, R., Mateo, C. \& Jimenez, C., Guide of strategies for urban regeneration,Instituto Valenciano de la, Edificación: Valencia, 2015.

[10] Terán, F., El pasado activo: del uso interesado de la historia para el entendimiento y la construcción de la ciudad, Akal: Madrid, 2009. 